$\begin{gathered}\text { Науковий вісник НЛТУ України } \\ \text { Scientific Bulletin of UNFU } \\ \text { https://nv.nltu.edu.ua }\end{gathered}$
$\begin{gathered}\text { https://doi.org/10.36930/40310509 } \\ \text { Article received 18.10.2021 p. }\end{gathered}$
Article accepted 25.11.2021 p.
UDC 712.4(1-21):657.371

С. В. Роговський', О. Г. Олешко1, К. В. Жихарєва1, Ю. В. Струтинська1, А. В. Колотницька ${ }^{2}$

${ }^{1}$ Білочерківський національний аграрний університет, м. Біла Церква, Украӥна

${ }^{2}$ Управління благоустрою та екологї Білочерківської міськради, м. Біла Церква, Украӥна

\title{
СУЧАСНІ ПРОБЛЕМИ ІНВЕНТАРИЗАЦІЇ РОСЛИН У МІСЬКИХ НАСАДЖЕННЯХ I ДОСВІД ЇХ ВИРІШЕННЯ
}

\begin{abstract}
Розглянуто сучасні проблеми інвентаризації деревних рослин у міських насадженнях України. Проаналізовано сучасний стан, тенденції розвитку та проблеми інвентаризації зелених насаджень, наведено законодавчі акти, що регламентують інвентаризацію та їх відповідність сучасним інформаційним технологіям і новітнім методам. Обгрунтовано потребу вдосконалення нормативно-правової бази інвентаризації з урахуванням досвіду останніх 15 років і розвитку комп'ютерних технологій. Показано причини низької ефективності робіт з інвентаризації в містах і селах. Запропоновано шляхи комплексного вирішення проблем, пов'язаних з інвентаризацією багаторічних зелених насаджень, зокрема, вдосконалення інструктивних вимог до інвентаризації, використання сучасних приладів і технологій. Показано, що передумовою якісної інвентаризації є попереднє геодезичне знімання дерев та інших елементів ландшафту на території садово-паркового об'єкта. Узагальнено досвід створення комп'ютерної програми, яка дає змогу проводити інвентаризацію з використанням GPS навігації смартфона i передавати дані на спеціальний сайт з нанесенням на електронну карту міста місця знаходження рослини і даних про неї, що охоплює розміщення рослини на інтерактивній мапі міста та іiі фотографії. Програма проходить випробування в містах Біла Церква та Одеса і потребує певного вдосконалення, яке полягає у тому, що проведення інвентаризації та редагування результатів, які вносяться в базу даних, має здійснювати фахівець-дендролог за спеціально розробленою методикою. Розроблені пропозиції щодо удосконалення програми. Зокрема, запропоновано чітко визначити категорію насаджень та передбачити відповідні коміри для заповнення в електронному бланкові. Бланк для електронного заповнення повинен містити такі показники, як: вік деревних рослини, ії розміри (діаметр стовбура і крони, висота), санітарний стан та естетична і господарська цінність. Інвентарний номер повинен присвоюватися тільки деревам, які пройшли верифікацію фахівцем і нанесені на електронну карту міста. Бажано закласти в програму можливість збільшувати масштабування плану, що спростить уточнення місць зростання рослин під час верифікації результатів інвентаризації.
\end{abstract}

Ключові слова: зелені насадження; база даних; дерева; інвентаризація; ландшафтна таксація; комп'ютерна програма; моніторинг; облік; садово-парковий об'єкт.

\section{Вступ / Introduction}

Міські зелені насадження здійснюють істотний вплив на екологічний і кліматичний стан міста, на їх функціонування впливає низка антропогенних чинників: техногенне забруднення повітря і грунту, недостатньо продумані заходи із озеленення, невідповідний підбір асортименту тощо. Інвентаризація наявних насаджень у містах і селах $є$ важливим і необхідним етапом роботи, без якого неможливе планове ведення зеленого господарства. Розроблення якісних проєктів реконструкції садово-паркових об'єктів, як важливої складової частини сучасного міського господарства, їх збереження і розвиток базується на результатах інвентаризації насаджень на цих об'єктах з точністю до дере- ва/куща, оцінці їх стану, фінансового оцінювання відновної вартості й естетичної цінності різних типів насаджень.

Застосування у сфері благоустрою та озеленення сучасних інформаційних технологій дає змогу оперативно вносити й обробляти інформацію про структуру насаджень, площі об'єктів озеленення та їх стан. Підвищення ефективності управління зеленим фондом відбувається завдяки зручності оброблення інформації, їі зберігання та відтворення [1]. Цифрові мапи зелених насаджень відображають відомості про окремі екземпляри деревно-кущової рослинності на об'єктах і є інформаційною основою для планування заходів із догляду за насадженнями, вивчення динаміки їх стану у

\section{Інформація про авторів:}

Роговський Сергій Володимирович, канд. с.-г. наук, доцент, кафедра садово-паркового господарства.

Email: naukaspg@gmail.com; https://orcid.org/0000-0001-6600-3974

Олешко Олена Геннадіївна, канд. с.-г. наук, доцент, кафедра садово-паркового господарства. Email: olena-ole@ukr.net; https://orcid.org/0000-0001-5263-1347

Жихарєва Катерина Вячиславівна, асистент, кафедра садово-паркового господарства. Email: Landscape.spg@gmail.com Струтинська Юлія Вікторівна, асистент, кафедра садово-паркового господарства. Email: yuliana-st@ukr.net Колотницька Альона Володимирівна, начальник управління благоустрою та екологіï. Email: naukaspg@gmail.com

Цитування за Дсту: Роговський С. В., Олешко О. Г., Жихарєва К. В., Струтинська Ю. В., Колотницька А. В. Сучасні проблеми інвентаризації рослин у міських насадженнях і досвід їх вирішення. Науковий вісник НЛтУ України. 2021, т. 31, № 5. С. 60-66.

Citation APA: Rohovskyi, S. V., Oleschko, O. G., Jychareva, K. V., Strunynska, J. V., \& Kolotnicka, O. V. (2021). Current problems of plant inventory in urban plantations and experience in their solution. Scientific Bulletin of UNFU, 31(5), 60-66. https://doi.org/10.36930/40310509 
взаємозв'язку зі станом міського середовища, планування видового складу нових територій озеленення [8].

Об'єкт дослідження - нормативне забезпечення та методологія інвентаризації садово-паркових насаджень

Предмет дослідження - методи і засоби використання комп'ютерних технологій для інвентаризації зелених насаджень у Білій Церкві.

Мета роботи - дослідити наявні нормативні й організаційні проблеми інвентаризації рослин у міських насадженнях та розробити стратегії їх вирішення з урахуванням досвіду використання комп'ютерної програми і створення цифрової інтерактивної карти міста Біла Церква.

Для досягнення зазначеної мети визначено такі основні завдання дослідження:

1) проаналізувати сучасний стан, тенденції розвитку та проблеми інвентаризації зелених насаджень, законодавчо-нормативну базу та іiі відповідність вимогам сьогодення;

2) узагальнити досвід використання сучасних інформаційних технологій та новітніх методів для проведення інвентаризації на прикладі Білої Церкви;

3) виявити та проаналізувати недоліки програми, окреслити алгоритм проведення інвентаризації, визначити ключові моменти, які варто враховувати для отримання якісних результатів, запропонувати заходи 3 удосконалення процесу інвентаризації.

Наукова новизна отриманих результатів дослідження - вперше здійснено комплексний аналіз нормативних документів, що регулюють процес інвентаризації зелених насаджень в Україні, узагальнено досвід проведення інвентаризації за літературними джерелами та практику використання комп'ютерних технологій для обліку дерев і кущів із занесенням отриманих під час дослідження даних в інтерактивну відомість на сайті, а геолокації рослини на цифрову карту міста. Запропоновано заходи з удосконалення комп'ютерної програми та iii ефективного використання.

Практична значущість результатів дослідження зумовлена важливістю та необхідністю інвентаризації зелених насаджень та недосконалістю нормативних вимог і наявних методик та можливістю пришвидшення інвентаризації і покращення iï результатів завдяки використанню комп'ютерних технологій і програм.

Аналіз останніх досліджень та публікацій. Ухвалюючи Закон "Про благоустрій населених пунктів" у 2005 р., законодавець мав намір врегулювати правові відносини у сфері благоустрою, зокрема і питання створення та утримання зелених насаджень. Зокрема, у пункті 5 ст. 27 цього Закону зазначено: "У містах та інших населених пунктах ведеться облік зелених насаджень та складається їх реєстр за видовим складом та віком. Облік зелених насаджень проводиться органами місцевого самоврядування". Закон вимагав, щоб кожен орган місцевого самоврядування розробив "Правила благоустрою території населеного пункту", в яких би визначив вимоги щодо утримання зелених насаджень на об'єктах благоустрою загального користування (міських лісів, парків, скверів, бульварів, садів, рекреаційних зон тощо) [15]. Фактично ще до ухвалення цього закону наказом Державного комітету з будівництва, архітектури та житлової політики № 226 від 24.122001 р. було затверджено "Інструкцію $з$ інвентаризації зелених насаджень у населених пунктах України". Згідно 3 вимогами Інструкції метою інвентаризації $€$ :

- отримання достовірних даних щодо кількісних і якісних характеристик зелених насаджень на території населеного пункту;

- посилення відповідальності балансоутримувачів, власників чи користувачів земельних ділянок, підприємств, організацій, установ, на території яких розташовані зелені насадження за збереження зелених насаджень;

- сприяння створенню та формуванню високодекоративних й екологічно ефективних і стійких до несприятливих умов навколишнього природного середовища насаджень;

- використання результатів інвентаризації під час розроблення у населених пунктах програм розвитку зеленого господарства;

- використання даних інвентаризації для відновлення, реконструкції та експлуатації об'єктів зеленого господарства i проведення в разі потреби профілактичних, лікувальних заходів; організації невиснажливого використання озеленених територій;

- встановлення відповідності кількості зелених насаджень чинним будівельним та санітарним нормам [17]

Згідно з вимогами цієї інструкції відповідальність за проведення інвентаризації покладено на органи місцевого самоврядування, балансоутримувачів, власників чи користувачів земельних ділянок, на підприємства, організації, установи, на території яких розташовані зелені насадження. Передбачалось, що інвентаризація має проводитися не рідше ніж один раз на п'ять років 3 квітня по жовтень підприємствами, організаціями, які мають на це право, а також балансоутримувачами об'єктів благоустрою державної чи комунальної форми власності, які мають технічні можливості та відповідних фахівців [17].

За інструкцією 3 проведення технічної інвентаризації та паспортизації об'єктів благоустрою населених пунктів, що затверджена наказом № 550 Міністерства регіонального розвитку, будівництва та житлово-комунального господарства України від 29.102012 р., інвентаризація зелених насаджень проводиться за попередньою інструкцією, що затверджена ще у 2001 р. і ніяких змін до неї внесено не було [10].

Під час інвентаризації необхідно:

- визначити загальну площу, зайняту об'єктами зеленого господарства, зокрема деревами, чагарниками, квітниками, газонами, стежками тощо;

- встановити кількість дерев і кущів за видами насаджень, породами, віком, діаметром стовбурів дерев на висоті 1,3 м та стану їхнього утримання;

- визначити вартість об'єкта загалом і його окремих ділянок.

Інструкція наголошує на необхідності вчасного внесення змін, які відбулися в зелених насадженнях, у креслення, паспорти об'єктів зеленого господарства та зведені дані про зелені насадження населеного пункту. В ній детально та послідовно описано вимоги щодо проведення інвентаризації зелених насаджень та наведено форму паспорта об'єкта озеленення.

Треба зазначити, що затвердження цього документа дало змогу уніфікувати роботи з інвентаризації зелених насаджень в Україні і сприяло якісному виконанню робіт у деяких містах. Зокрема роботи 3 інвентаризації об'єктів загального користування було виконано у Львові, Рівному, Хмельницькому, Києві, Дніпрі та деяких інших містах $[5,11]$. Проте повної реалізації завдань щодо обліку зелених насаджень в містах і селах України досягнути не вдалось. Станом на 2016 р. тільки 12 \% населених пунктів України мали програми розвит- 
ку зелених зон, варто зазначити, що у містах ця частка зростала до 57 \% [6]. Часто програми приймали без вивчення реального стану справ, не спиралися на результати інвентаризації і мали декларативний характер.

За даними О. П. Ігнатенка, в Україні загальна площа зелених насаджень в містах і селах становить 652 тис га, площа насаджень загального користування - 182 тис. га. За його розрахунками на одного жителя припадає $145 \mathrm{~m}^{2}$ зелених насаджень, зокрема $4 \mathrm{~m}^{2}$ насаджень загального користування [6]. Уже ці цифри свідчать про важливість проблеми обліку цих насаджень і необхідності термінового її вирішення.

Підсумовуючи наведене вище, варто зазначити, що зелені насадження населених пунктах - величезне суспільне багатство, яке через відсутність інвентаризації та грошової оцінки у багатьох випадках не має господаря. На сьогодні більшість садово-паркових об'єктів, зокрема і загального користування, досі не мають паспортів. Інвентаризацію насаджень на їх території не проводили, тому об'єктивних даних щодо площ насаджень загального користування, спеціального призначення та обмеженого користування, кількості дерев та кущів, що ростуть на цих територіях, їх видового складу, віку і санітарного стану, зазвичай, немає. Наявна методика визначення балансової вартості дерев і кущів недосконала, що не сприяє їх збереженню та відновленню $[4,7,12]$.

Матеріали та методи дослідження. Під час проведення дослідження використовували загальнонаукові методи аланіну і синтезу, індукції і дедукції, порівняння. Аналізували спеціальні методи інвентаризації та ландшафтної таксації та можливості комп'ютерної програми, спеціально розробленої для обліку зелених насаджень і нанесення їх на цифрову інтерактивну карту міста.

\section{Результати дослідження та їх обговорення / Research results and their discussion}

Причинами незадовільного стану з інвентаризацією зелених насаджень у містах і селах України, на нашу думку, є:

- систематичні реорганізації органів управління в державі, зміна владних повноважень міністерств та відомств, кадрові перестановки i, як наслідок, втрата контрою за процесом;

- недостатне, часто залишкове, фінансування питань, пов'язаних із благоустроєм і озелененням у більшості міст і сіл;

- дефіцит кваліфікованих виконавців, які добре знають дендрологію і мають відповідну кваліфікацію для проведення інвентаризації зелених насаджень;

- слабка нормативно-правова база на рівні держави, відсутність адміністративних важелів впливу на органи місцевого самоуправління і керівників підприємств за невиконання вимог Закону та Інструкції;

- недостатне розуміння керівниками органів самоуправління і державної влади важливості зелених насаджень як елемента живої природи в містах та їх екологічної, містотвірної, декоративно-естетичної ролі, особливо в умовах сучасних змін клімату i, як наслідок, відсутність програм розвитку озеленених територій та затверджених правил їх створення, реконструкції та експлуатації.

Та й сама Інструкція 3 інвентаризації, як показує досвід їі використання, потребує удосконалення. Підстав для цього $є$ багато, а саме:

По-перше, у зв'язку із адміністративною реформою і децентралізацісю змінився адміністративний устрій в державі, з'явилися об'єднані громади, які власне і опікуються благоустроєм населених пунктів та несуть від- повідальність за розвиток зелених зон на своїй теритоpiï. Нині якість озеленення і благоустрою має вирішальне значення для рекреації місцевих жителів і туристичної привабливості населених пунктів, впливає на їх екологічну й естетичну привабливість, часто визначає напрям економічного розвитку і сприяє фінансовій самодостатності. Отже, саме об'єднані громади та ïх представницькі органи зацікавлені в проведенні якісної інвентаризації зелених насаджень і складанні паспортів на об'єкти озеленення як основи подальшого їх розвитку.

По-друге, підписання договору про асоціацію між Україною та ЄС вимагає уніфікації українського законодавства в усіх сферах, зокрема і в питаннях проектування, будівництва та експлуатації садово-паркових об'єктів, які $€$ важливою складовою частиною сучасного міського господарства. Не менш важливим є виконання Україною взятих на себе зобов'язань внаслідок ратифікації Європейської ландшафтної конвенції [4].

По-третє, за останні 20 років ухвалено низку законів і затверджено підзаконних актів, ДБНів, які впливають на організацію благоустрою, озеленення, що потребує удосконалення процесу інвентаризації зелених насаджень.

По-четверте, бюро технічної інвентаризації, на які свого часу покладалась відповідальність за проведення інвентаризації зелених насаджень, ніколи цього завдання не виконували, не маючи організаційних та технічних можливостей, а нині і взагалі втратили значну частину своїх функцій.

По-п'яте, внаслідок технічного прогресу істотно змінилися можливості інструментального забезпечення проведення інвентаризації. Нині широко використовують новітні геодезичні прилади 3 можливостями GPS навігації, які дають змогу швидко та якісно підготувати підоснову для інвентаризації. Для визначення висоти дерев та заміру віддалей і розмірів використовують точні лазерні далекоміри. Розроблено комп'ютерні програми для ідентифікації видів рослин за фото вегетативних і генеративних органів (PlanNet). Розробляють методологію використання квадрокоптерів під час інвентаризації [16]. На черзі розроблення комп'ютерних програм, що забезпечуватимуть облік деревних рослин та нанесення їх на електронні карти міст і створення електронних баз даних - кадастру зелених насаджень [14].

По-шосте, фахівці були практичного досвіду проведення інвентаризації, який варто узагальнити та врахувати як у новій редакції "Інструкції з інвентаризації зелених насаджень", так і в спеціальному Законі "Про охорону зелених насаджень в містах та інших населених пунктах", який внесено до розгляду в комітетах Верховної ради, але так і не затверджено [2].

Як показує практика, інвентаризація зелених насаджень $є$ ключовим етапом для обліку наявного рослинного різноманіття на території садово-паркових об'єктів, що дає змогу отримати якісну і кількісну характеристику не тільки дендрофлори, а й елементів благоустрою, уточнювати площу об'єктів та на цій основі розробляти якісні проєкти реконструкції та перспективні і поточні плани розвитку зелених зон міста. Без достовірних даних інвентаризації неможливо ні планувати роботу зі зеленого господарства, ні розробляти проєкти реконструкції садово-паркових об'єктів і здійснювати будівництво.

Зважаючи на власний досвід інвентаризації багатьох садово-паркових об'єктів, окреслимо алгоритм прове- 
дення інвентаризації та наведено деякі ключові моменти, які варто враховувати для отримання якісних результатів. Першим і обов'язковим етапом інвентаризації парків, скверів, набережних або об'єктів обмеженого користування чи спеціального призначення має бути геодезичне знімання об'єктів, що розташовані на цій території, за допомогою сучасних геодезичних приладів та позначення місця розташування дерев, кущів, квітників i елементів благоустрою на плані ділянки за допомогою GPS приладів. Це не тільки спрощує роботу фахівців, які проводять інвентаризацію, а і в рази підвищує точність і якість виконаної роботи. Інвентаризація без виготовлення підоснови можлива тільки для вуличних насаджень, якщо як підоснову використовують детальний план міста.

У складі групи, яка здійснює інвентаризацію, має бути досвідчений дендролог, який може за візуальними ознаками точно визначити вид дерева чи куща, встановити його орієнтовний вік, а засобами інструментального вимірювання визначити діаметр стовбура та висоту рослин. Бажано, щоб на озброєнні ландшафтних таксаторів була не тільки мірна вилка, а і лазерний далекомір, що дасть змогу точніше встановлювати висоту дерев. Основними показниками, які мають заноситися до відомості робочого щоденника 3 інвентаризації, окрім порядкового номера, що відзначається на плані, мають бути українська і латинська назва рослини, іiі висота, діаметр стовбура на висоті 1,3 м, орієнтовний вік рослини, санітарний стан, що власне і передбачає Інструкція. Проте, на наш погляд, варто додатково ввести графу "Проекція крони", яка є досить інформативною і показує площу крони, що важливо особливо під час використання матеріалів для розроблення проектів реконструкції. Варто також добавляти графу "Примітка", в якій позначати особливості рослини (походження, пошкодження омелою, багатостовбурність тощо). Бінарна назва рослини, у т.ч. латиницею, важлива для точного визначення виду і культивару і дає змогу уникати двозначних назв і використання синонімів або місцевих назв. Реальні розміри рослини враховують під час встановлення віку і стану дерев, особливо під час реконструкції насаджень, а також для визначення їх балансової вартості. Діаметр крони, відтворений у масштабі на плані, дає можливість зрозуміти на скільки проекція крон сусідніх дерев перетинається та зрозуміти фітоценотичну структуру насадження, що особливо важливо під час реконструкції.

Під час камерального оброблення результатів інвентаризації підсумкової таблиці треба формувати у прогpaмi Excel. Ця комп'ютерна програма дає змогу згрупувати весь масив інформації за будь-яким показником: віком, санітарним станом, життєвою формою тощо, що спрощує подальший аналіз отриманої інформації та графічно зображувати певні яруси насадження в програмі Auto CAD.

Пропонуємо під час інвентаризації давати деревам естетично-господарську оцінку за п'ятибальною шкалою, а саме:

5 - особливо цінні дерева (здорові, дорослі високодекоративні), підлягають обов'язковому збереженню;

4 - цінні (дорослі, але дещо пригнічені сусідніми древами або ослаблені, внаслідок ураження шкідниками та хворобами, незначно заселені омелою), вони зазвичай зберігаються, але потребують проведення формувального обрізування та інших агротехнічних заходів;

3 - молоді здорові дерева самосійного походження, підлягають видаленню або пересаджуванню;

2 - дерева, що втратили декоративність (всихаючі, старі аварійні, сильно заселені омелою, грибами трутовиками тощо) - підлягають видаленню під час санітарних рубань;

1 - сухостійні аварійні дерева - підлягають обов'язковому видаленню.

Такий поділ, виконаний фахівцем, що здійснював інвентаризацію, дасть змогу ефективно використовувати дані інвентаризації як для планування робіт, так і для розроблення проєктів реконструкції. Під час розроблення проєкту реконструкції проектувальнику важливо мати якомога повну і точну інформацію як про наявні на ділянці дерева і кущі, так і про рельєф, характер освітлення, природну трав'яну рослинність тощо. Ось чому під час інвентаризації рослинності на певних типових ділянках, що зазвичай обмежені доріжками, стежками чи іншими орієнтирами, важливо провести ландшафтний опис ділянки. Під час такого опису вивчають та позначають на плані межі цієї ділянки, а самі ділянки (виділи) нумерують на плані. У ході роботи описують характер рельєфу, напрям та крутизну схилу, повноту насадження і рівень освітлення під наметом дерев, позначають на плані конфігурацію груп і масивів, вказують ярусність насадження та панівні види рослин в яруcax, склад надгрунтової трав'яної рослинності, тобто дають ландшафтну і фітоценотичну оцінку насадженню. А. М. Мельник, Г. Г. Гриник та О. М. Гриник рекомендують окремо за кожним таксаційним виділом оцінювати такі основні ландшафтні показники: тип ландшафту, рекреаційну стійкість, стадію рекреаційної дигресії, клас прохідності, клас проглядності, рекреаційну оцінку [5]. Уся ця інформація дає змогу об'єктивно оцінити наявний фітоценоз і якісно доповнити результати інвентаризації.

Останнім часом під час інвентаризації дедалі частіше використовують можливості квадрокоптерів, за допомогою яких отримують інформацію, яка доповнює дані ландшафтної таксації та подеревної інвентаризації. Зокрема з висоти пташиного польоту розгледіти конфігурацію груп і масивів, провести діагностику санітарного стану за візуальними показниками. Нині розробляють методики для дистанційної інвентаризації [16]. Проте на нинішньому етапі фото- і відеоматеріали є важливою, але доповнювальною частиною ландшафтної таксації та інвентаризації. Ці матеріали дають змогу менш затратно проводити інвентаризацію та здійснювати оперативний моніторинг стану насаджень.

Однією $з$ найскладніших проблем $є$ те, що на сьогодні результати інвентаризації відображаються тільки в паспорті об'єкта та графічних матеріалах, які виготовляються тільки в кількох екземплярах, і не доступні для широкого загалу. Сучасні комп'ютерні технології дають змогу мати цифрову інтерактивну карту міста чи іншого населеного пункту та нанести на цю карту як наявні садово-паркові об'єкти в їх реальних межах, так і дерева, кущі, а також елементи благоустрою, виявлені в ході інвентаризації на території цих об'єктів. Досвід створення таких цифрових баз даних є в деяких містах світу $[2,14]$. В Україні подібний пілотний проєкт реалізується в місті Біла Церква за сприяння Фонду Фрідріха 
Науманна "За свободу". Він має назву Smart Green Біла Церква і має за мету нанесення усіх насаджень на інтерактивну карту міста. За задумом розробників сучасні супутникові технології дають змогу точно встановити місце геолокації смартфона чи планшета, а отже, підійшовши до дерева або куща, є можливість перенести дані про місце розташування об'єкта на цифрову карту міста (рисунок). У режимі реального часу такі дані, як назва рослини, іiї висота, діаметр стовбура, санітарний стан та власне іiі фотографія із смартфона або планшета,

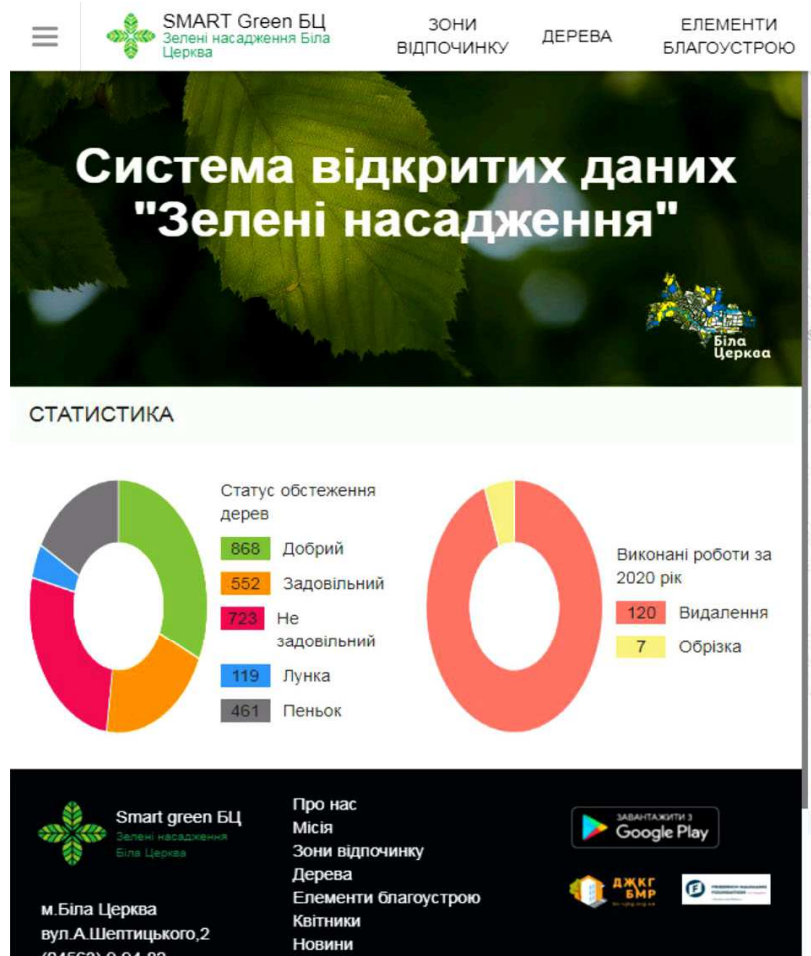

Рисунок. Інтерфейс бази даних для інвентаризації і оцінки зелених насаджень "Smart Green Біла Церква" / Database interface for inventory and assessment of green areas "Smart Green Bila Tserkva"

За задумом розробників іiі можливості дають змогу проводити інвентаризацію дерев у місці усіма охочими, що мають доступ до сайту. Проте реальність виявилася дешо складнішою. Любительські знімки та назва рослини, переважно родова, виконані волонтерами-любителями, навіть після присвоєння номера рослині реальної цінності не мають та і встановлення геолокації рослин виявилося далеко недосконалим. Тому скористатися цими даними для прийняття управлінських рішень неможливо. Виявилось, що створення справжньої інформативної бази даних щодо системи зелених насаджень міста потребує професійного підходу та істотного вдосконалення комп'ютерної програми.

Для виправлення такої ситуації ми запропонували низку заходів:

1) заповнення бази даних має відбуватися за спеціальним алгоритмом і виконуватиметься підготовленими групами фахівців, які цілеспрямовано за єдиною методикою будуть проводити ландшафтну таксацію та інвентаризацію садово-паркових об'єктів на території міста;

2) перед початком інвентаризаційної роботи виконавець уточнює місце геолокації безпосередньо біля дерева досліджуваного;

3) назва рослин повинна включати родову і видову назву і дублюватися латиницею, за потреби латинську назву може вносити адміністратор;

4) запропоновано розширити перелік характеристик санітарного стану рослин, окрім оцінок "добрий", "задо- потрапляють в електронну базу даних. Розробниками програми передбачено можливість наповнення бази даних усіма користувачами мобільного додатку на відкритому порталі, тобто волонтерами, звичайними мешканцями міста. Отже кожне дерево або кущ матиме свій інвентарний номер, і відправивши його фотографію на сайт, можна буде отримати всі дані про цю рослину. Нині цю програму як експериментальну використовують не тільки в Білій Церкві, а і в Одесі.

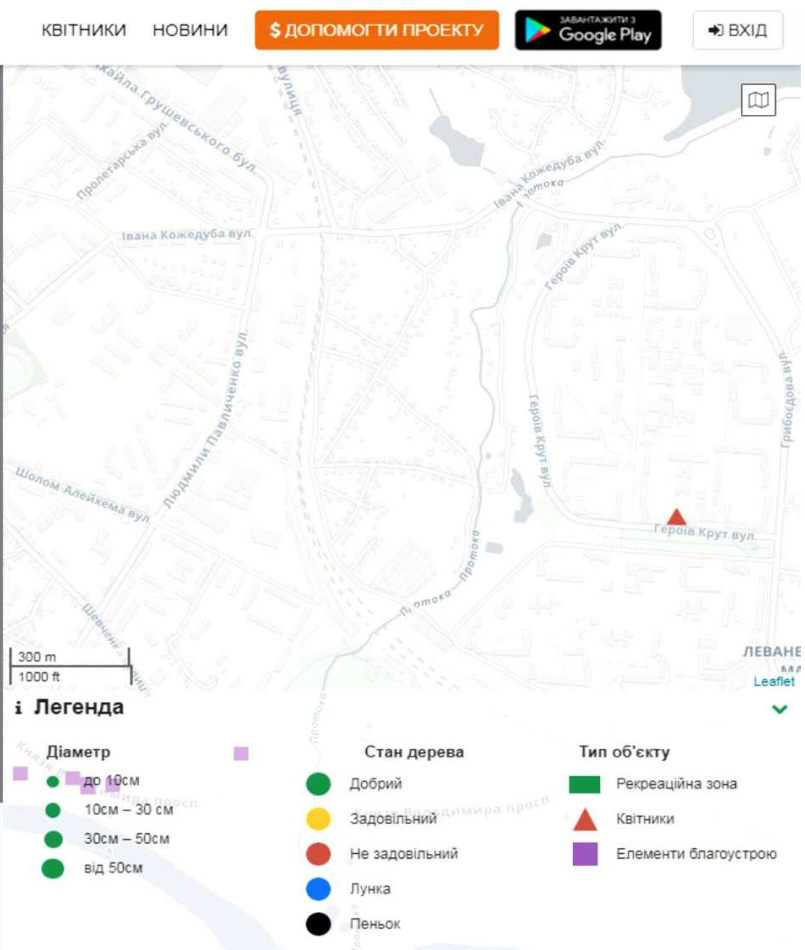

вільний", "незадовільний" передбачити примітки, що характеризують причини погіршення санітарного стану та використати запропоновану вище п'ятибальну шкалу оцінки;

5) в окремій графі передбачене формулювання пропозицій щодо заходів, спрямованих на покращення санітарного стану, а саме: формувальне обрізування гілок, санітарне обрізування гілок, уражених омелою, обрізування сухих гілок.

6) заміри діаметра стовбура та висоти дерев доцільно проводити 3 використанням спеціальних вимірювальних приладів.

Зазначимо, що розробники врахували наші зауваження і програма стала більш інформативною і точною. Отримані під час інвентаризації дані в режимі реального часу передаються на сайт, а також паралельно записуються в щоденник інвентаризації. Після камерального оброблення результатів дослідження виготовляється документація: план з нанесеними рослинами, відомість інвентаризації, паспорт об'єкта, звіт про склад і стан дендрофлори й об'єкта благоустрою. На основі цих даних адміністратор сайту або керівник групи, отримавши відповідний доступ, вносить корективи в електронну базу даних, здійснюючи верифікацію, та присвоює інвентарний номер рослині та вказує номер штрих-коду, що закріплюється на дереві під час інвентаризації. Паралельно уточнюють місця геолокації, назви рослин, зокрема і латинські назви виду або культивару. Переві- 
ряється правильність назви виду насадження, в якому зростає деревна рослина, а також іiі назва, санітарний стан, кількісні показники (висота, діаметр стовбура та проекція крони, вік, кількість стовбурів, враження омелою тощо). Важливо під час оцінювання деревних рослин відразу встановити естетично-господарську цінність кожного екземпляра, що дасть змогу зважено приймати рішення під час реалізації заходів 3 догляду чи реконструкції. Обов'язково на інтерактивній карті міста позначають межі садово-паркового об'єкта та вказують його назву.

Використовуючи отримані під час інвентаризації дані, фахівці зможуть розраховувати балансову вартість кожної деревної рослини за спеціальною методологією [7]. Тільки після перевірки даних інвентаризації фахівцем вони стають доступними для загального користування. Це дає змогу пошуковій системі наводити дані, що характеризують садово-парковий об'єкт: площа, рельєф, сусідні території, техніко-економічні показники, кількість дерев і кущів, кількість видів і культиварів, середній вік дерев і кущів, дата створення, реконструкції, останньої інвентаризації. У той же час система за номером рослини або номером штрих-коду, зможе видати будь кому на його запит інформацію про рослину (наукова назва, вік, висота, діаметр стовбура та проєкція крони, санітарний стан, місце розташування на цифровій карті міста та зображення рослини на фото). Це дасть змогу громадянам контролювати стан насаджень, а владі володіти об'єктивною інформацією, що сприятиме прийняттю виважених управлінських рішень, а також застосовувати штрафні санкції до порушників, зважаючи на об'єктивну офіційно затверджену балансову вартість кожної рослини. Об'єктивний облік дерев і кущів, їх грошова оцінка сприятимуть їх охороні та збереженню, будуть підставою для стягнення шкоди за знищення дерева чи газону з винної особи в судовому порядку. Наявність такої бази дасть змогу здійснювати об'єктивний моніторинг за станом насаджень і відслідковувати тенденції їх стану та розвитку. Вірогідно подальше вдосконалення програми дасть змогу розміщувати інформацію, яка об'єктивно характеризує ландшафтно-естетичну цінність садово-паркового об'єкта.

\section{Висновоки / Conclusions}

На основі аналізу нормативних документів та практики інвентаризації зелених насаджень в Україні встановлено:

1. Нормативна база, викладена в Інструкції та інших нормативних документах, застаріла, не повною мірою відповідає вимогам сьогодення і потребує удосконалення.

2. Під час проведення інвентаризації нині недостатньо використовують методи ландшафтної таксації, що об'єктивно оцінюють ландшафт, а не тільки його елементи.

3. Наявна методика визначення балансової вартості окремого дерева не досконала, вона не враховує його санітарний стан, естетичну та господарську цінність, місце зростання та не дає змогу запропонувати заходи з подальшого використання рослини та відшкодувати його реальну вартість внаслідок зумисного пошкодження чи знесення.

4. Проаналізовано досвід використання GPS технологій і комп'ютерної програми для інвентаризації насаджень у Білій Церкві, показано переваги та недоліки програми і запропоновано заходи з їі удосконалення.
5. Запропоновано п'ятибальну шкалу для санітарногосподарського оцінювання дерев під час інвентаризації та заходи, реалізація яких покращить методологію оцінювання дерев, кущів та елементів благоустрою під час інвентаризації.

\section{References}

1. Bidolakh, D. I., \& Lakyda, P. I. (2019). Inventaryzatsiia zelenykh nasadzhen $\mathrm{z}$ vykorystanniam suchasnykh informatsiinykh tekhnolohii. Lisove $i$ sadovo-parkove hospodarstvo, 16, 126-132. Retrieved from: http://journals.nubip.edu.ua/index.php/lis/article/view/13631. [In Ukrainian].

2. Bidolakh, D. I., Bilous, A. M., \& Kuzovych, V. S. (2018). Vymiriuvannia vysoty derev i chaharnykiv iz vykorystanniam kvadrokoptera. Scientific Bulletin of UNFU, 28(1), 24-28. https://doi.org/10.15421/40280104

3. Cadastre. (2018). Update on the OGD Cadastre of Trees of Vienna in OpenStreetMap. Retrieved from: https:/gisforge.wordpress.com/2015/01/02/update-on-the-ogd-cadastre-of-trees-of-vienna-in-openstreetmap/

4. Ihnatenko, O. P. (2016). Derzhavne rehuliuvannia sfery blahoustroiu naselenykh punktiv: dys. doktora nauk $\mathrm{z}$ derzhavnoho upravlinnia. Kyiv, 471 p. [In Ukrainian].

5. Melnyk, V. Y., \& Denysiuk, N. V. (2020). Taksonomichna ta ekolohichna struktury dendroflory parkiv i skveriv mista Rivne. Publishing House "Baltija Publishing 2020/10/2, 1-18. [In Ukrainian].

6. Melnyk, Yu. A., Hrynyk, H. H., \& Hrynyk, O. M. (2019). Pidsumky inventaryzatsii zelenykh nasadzhen dendroparku "Podillia" mista Khmelnytskyi. Scientific Bulletin of UNFU, 29(7), 101108. https://doi.org/10.15421/40290720

7. Metodyka. (2016). Pro zatverdzhennia Metodyky vyznachennia vidnovnoi vartosti zelenykh nasadzhen: zatv. nakazom Ministerstva z pytan zhytlovo-komunalnoho hospodarstva Ukrainy vid 12.05.2009 № 127. [In Ukrainian].

8. Mullaiarova, P. I. (2019). Sozdanie tcifrovykh skhem ozeleneniia dlia effektivnogo upravleniia gorodskimi zelenymi nasazhdeniiami, 79-88. https://doi.org/10.33764/2618-981Kh-2019-4-2-79-88

9. Nakaz Ministerstva. (2012). Instruktsiia $z$ provedennia tekhnichnoi inventaryzatsii ta pasportyzatsii obiektiv blahoustroiu naselenykh punktiv: zatv. Nakazom Ministerstva rehionalnoho rozvytku, budivnytstva ta zhytlovo-komunalnoho hospodarstva Ukrainy vid 29.10.2012, № 550. [In Ukrainian].

10. Nakaz. (2001). Instruktsiia z inventaryzatsii zelenykh nasadzhen: zatv. Nakazom Derzhavnho komitetu z budivnytstva, arkhitektury ta zhytlovoi polityky 226 vid 24.12 2001, № 17. [In Ukrainian].

11. Poriadok. (2019). Pro zatverdzhennia Poriadku provedennia inventaryzatsii zemel ta vyznannia takymy, shcho vtratyly chynnist, deiakykh postanov Kabinetu Ministriv Ukrainy: postanova Kabinetu Ministriv Ukrainy vid 5 chervnia 2019, № 476. [In Ukrainian]

12. Rohovskyi, S. V. (2016). Metodyka vyznachennia vidnovnoi vartosti derev u zelenykh nasadzhenniakh naselenykh mists. Scientific Bulletin of UNFU, 26(4), 45-50. https://doi.org/10.15421/40260407

13. Rohovskyi, S. V. (2019). Suchasni problemy stvorennia i utrymannia zelenykh nasadzhen u naselenykh punktakh Ukrainy. Scientific Bulletin of UNFU, 29(1), 9-16. https://doi.org/10.15421/40290101

14. Tree Map. (2018). New York City Street Tree Map. Retrieved from: https://tree-map.nycgovparks.org/learn/about

15. Zakon Ukrainy. (2005). Pro blahoustrii naselenykh punktiv: Zakon Ukrainy N 2807, vid 5.09.2005. [In Ukrainian].

16. Zakon Ukrainy. (2005). Yevropeiska landshaftna konventsiia: ratyfikovano Zakonom N 2831-IV (2831-15) vid 07.09.2005, VVR, $N$ 51, st. 547. [In Ukrainian].

17. Zakon Ukrainy. (2008). Iz zminamy, vnesenymy zhidno iz Zakonom N 509-VI (509-17) vid 16.09.2008, VVR. N 48, st. 358. [In Ukrainian].

18. Zakonu Ukrainy. (2011). Pro okhoronu zelenykh nasadzhen v mistakh ta inshykh naselenykh punktakh: proekt Zakonu Ukrainy № 9628 vid 21.12.2011. [In Ukrainian]. 
${ }^{1}$ Bila Tserkva National Agrarian University, Bila Tserkva, Ukraine

${ }^{2}$ Department of Housing and Communal Services of Bila Tserkva City Counci, Bila Tserkva, Ukraine

\section{CURRENT PROBLEMS OF PLANT INVENTORY IN URBAN PLANTATIONS AND EXPERIENCE IN THEIR SOLUTION}

The paper considers current problems of woody plants inventory in urban plantations. The recent state, development trends and problems of green plant inventory, legal framework and its compliance for use in modern information technologies and the latest methods are analyzed. The necessity of the inventory legal base improvement that takes into account the experience of the last 15 years and the development of computer technologies is substantiated. The study lists the reasons for low efficiency of inventory works in cities and villages and proposes ways of the complex solution of the problems connected with of perennial plantings inventory, in particular, improvement of instructive requirements concerning the inventory, use of modern devices and technologies. The study reveals that a preliminary geodetic survey of trees and other elements of the landscape on the territory of the garden and park object is the prerequisite for a quality inventory. The study summarizes experience in developing a computer program that allows carrying out inventory using smartphone GPS navigation. It can further transfer data to a special site with an electronic map of the city location of the plant and data about it, including the location of the plant on an interactive map of the city and its photos. The program is being tested in the cities of Bila Tserkva and Odessa and needs some improvement, which implies that the inventory and editing of the results entered into the database should be carried out by a dendrologist according to a specially developed methodology. The authors have developed some proposals for the program improvement. In particular, it is proposed to clearly define the category of plantings and provide appropriate blanks to fill in the electronic form. The form for electronic filling should contain indicators such as age of woody plants, their sizes (trunk and crown diameter, height), a sanitary condition and aesthetic and economic value. The inventory number should be assigned only to trees that have been verified by a specialist and pointed on an electronic city map. It is desirable to include the possibility to increase the plan scaling in the program, which will simplify the specification of plant growth sites in the course of inventory results verification.

Keywords: greenery; database; trees; inventory; landscape assessment; computer program; monitoring; accounting; garden and park object. 